\title{
Analysis of Ferromagnetic Resonance Linewidth in Ni Thin Film Fabricated by Electrodeposition Method
}

\author{
Dong Young Kim and Seok Soo Yoon* \\ Department of Physics, Andong National University, Andong 760-749, Korea
}

(Received 31 March 2014, Received in final form 4 April 2014, Accepted 7 April 2014)

\begin{abstract}
We obtained resonance field $\left(H_{r e s}\right)$ and linewidth $\left(\Delta H_{P P}\right)$ from measured ferromagnetic resonance signal in the functions of polar angle $\left(\theta_{H}\right)$ in Ni thin film of $240 \mathrm{~nm}$ thickness fabricated by electrodeposition method. The angular dependence of $H_{\text {res }}$ was well fitted with the calculated ones. We confirmed that the g-factor and effective demagnetization field were 2.18 and $445 \mathrm{emu} / \mathrm{cc}$ by the theoretical analysis of the resonance field, respectively. The angular dependence of $\Delta H_{P P}$ showed very large values at in-plane direction $\left(\theta_{H}=90^{\circ}\right)$, which could not explained by the homogenous linewidth due to the Gilbert damping and inhomogeneous linewidth due to the angular variations and magnetization variations by the surface layer. Therefore, we considered the spin wave scattering (two magnon scattering) process in order to analyze the measured inhomogeneous linewidth, which was appeared in thicker film than the critical thickness of $50 \mathrm{~nm}$. The defect medicated spin wave scattering played a key role in the electrodoposited Ni thin film of $240 \mathrm{~nm}$ thickness.
\end{abstract}

Keywords : ferromagnetic resonance, linewidth, damping constant, spin wave scattering

\section{전기 도금법으로 제작한 $\mathrm{Ni}$ 박막의 강자성 공명 선폭 분석}

\author{
김동영 · 윤석수* \\ 안동대학교 물리학과, 경북 안동시 경동로 $1375,760-749$
}

(2014년 3월 31일 받음, 2014년 4월 4일 최종수정본 받음, 2014년 4월 7일 게재확정)

\begin{abstract}
전기 도금법으로 제작한 $\mathrm{Ni}$ 박막 $(240 \mathrm{~nm})$ 의 자기장 각도에 따른 강자성 공명 신호를 측정하여 공명 자기장 $\left(H_{r e s}\right)$ 및 선폭 $\left(\Delta H_{P P}\right)$ 을 도출하였다. 자기장 각도에 따른 $H_{r e s}$ 는 이론적인 분석 결과와 일치하였으며 이들 결과로부터 제조된 $\mathrm{Ni}$ 박막의 g-factor는 2.18 임을 확인하였다. 자기장 각도에 따른 $\Delta H_{P P}$ 는 박막의 수평 방향에서 매우 큰 값을 나타냈으며, 이러한 특성은 Gilbert 감쇠에 기 인하는 균일한 선폭 특성과 약 $1 \mathrm{~nm}$ 의 표면에서 나타나는 자구들의 각도 변화 및 자화량 변화에 기인하는 비균일한 선폭 특성 으로는 설명되지 않았다. 따라서 본 연구에서는 박막의 두께가 $10 \mathrm{GHz}$ 에서 임계 두께(약 $50 \mathrm{~nm})$ 이상으로 증가하면 나타나는 two magnon scattering 이론을 적용하여 비균일한 선폭 특성을 분석하였다. 이러한 분석 결과로부터 전기 도금법으로 제작한 $240 \mathrm{~nm}$ 두께를 갖는 Ni 박막에서 각도에 따른 비균일한 선폭 변화의 주요한 원인은 재료 내부 결함들에 의한 스핀파 산란이었 음을 알 수 있었다.
\end{abstract}

주제어 : 강자성 공명, 선폭, 감쇠상수, 스핀파 산란

\section{I. 서 론}

고주파수에서 동작하는 자성 소자(magnetic device)들은 자 성 재료의 자기 이완 특성에 대한 분석을 요구한다. 자성 박 막 재료의 자기 이완 현상은 감쇄 효과가 작은 경우에 대하

(C) The Korean Magnetics Society. All rights reserved.

*Corresponding author: Tel: +82-54-820-5450,

Fax: +82-54-823-1628, e-mail: yoon@andong.ac.kr
여 LLG(Landau-Lifshitz-Gilbert) 운동 방정식을 사용하여 설 명되고 있다. 이러한 자기 이완은 이방성 상수가 작은 경우 고주파수인 마이크로파를 인가하여 자기장의 세기에 따른 마 이크로파 에너지의 흡수를 측정하는 강자성 공명 (ferromagnetic resonance, FMR) 신호로부터 분석된다. 즉 자성 재료가 인가 자기장에 의하여 단자구를 형성하는 경우 자구모멘트의 세차운동 주파수와 마이크로파 주파수가 공명 조건을 만족하는 상태에서 마이크로파 에너지의 흡수가 최대 
가 되는 자기장을 공명 자기장 $\left(H_{r e s}\right)$ 이라고 한다. 이러한 공명 자기장은 자성 박막 재료의 자기 이방성 에너지와 관련되어 있으므로 자성재료의 자기 이방성 상수 분석에 사용되고 있 으며, 자성 재료의 고주파수 특성을 결정 짖는 g-factor 측정 에 사용되고 있다[1-8].

마이크로파 흡수를 한번 미분한 강자성 공명 신호는 자기 장의 세기에 따라 최대 및 최소값을 보이며 이들 자기장의 차이인 선폭 $\left(\Delta H_{P P}\right)$ 은 자성 재료의 자기 이완 특성과 관련된 다. 자화가 균일한 자성 재료의 경우에는 재료 고유의 이완 특성인 Gilbert 감쇠 상수 $\alpha$ 와 관련된 균일한 선폭으로 설명 되고 있다[4]. 그러나 자화가 비균일한 경우에는 자성 박막의 두께에 따라서 두 가지 특성으로 구분된다. 자성 박막의 두 께가 임계두께 이하에서는 자성재료의 국부적인 자화 각도 변 화 및 자성 박막의 표면에 존재하는 자화량 변화가 주요한 원인으로 작용한다. 한편, 자성 박막의 두께가 임계 두께 이 상으로 증가하면 스핀파가 생성되어 진행하게 되며, 이들 스 핀파는 재료 내에 존재하는 결함들에서 산란을 일으켜 선폭 을 증가시키게 된다[9-13]. 이러한 스핀파 산란 특성은 two magnon scattering(TMS)으로 설명되고 있으며, 두꺼운 박막 재료에 대한 자기 이완 특성을 결정하는 요인으로 작용한다 [14]. 최근에는 고밀도 하드디스크 메모리 소자의 정보 저장을 위한 자화 반전에 마이크로파 에너지를 이용하기 위한 연구가 진행되고 있다. 특히, 수직 자기 이방성 자성 재료의 스위칭 속도에 영향을 주는 이완 특성 분석을 위하여 선폭에 대한 관 심도가 새로이 증가하고 있으며, 수직 이방성 미디어 재료의 선폭 변화는 주로 $\mathrm{TMS}$ 에 기인함을 보여주고 있다[15]. 이러한 TMS 효과는 포화 자화량이 작고 주파수가 증가할수록 두드러 지게 나타나는 현상이다[14]. 따라서 약 $10 \mathrm{~nm}$ 의 두께를 갖는 $\mathrm{NiFe}(800 \mathrm{emu} / \mathrm{cc})$ 또는 $\mathrm{Co}(1400 \mathrm{emu} / \mathrm{cc})$ 박막의 경우 $10 \mathrm{GHz}$ 대역의 마이크로파를 사용하여 선폭을 측정할 경우 TMS 현상 을 구분하기 어려울 뿐만 아니라 연구결과가 미미하다.

따라서 본 연구에서는 $\mathrm{TMS}$ 를 구분하기 위하여 자화량이 $\mathrm{NiFe}$ 또는 $\mathrm{Co}$ 보다 작은 재료로 $\mathrm{Ni}$ 박막을 선택하였으며, 전 기 도금법으로 $240 \mathrm{~nm}$ 의 두께를 갖는 박막을 제작하였다. 제 작된 $\mathrm{Ni}$ 박막은 $9.8 \mathrm{GHz}$ 의 마이크로파를 사용하여 자기장 각 도에 따른 강자성 공명 신호를 측정하였다. 자기장 각도에 따 른 강자성공명 자기장 $\left(H_{r e s}\right)$ 에 대한 이론적인 분석 결과를 토 대로 선폭 변화 $\left(\Delta H_{P P}\right)$ 에 영향을 주는 균일한 특성과 비균일 한 특성을 구분하여 분석하였으며, 비균일한 선폭의 특성 분 석을 위하여 TMS에 의한 영향을 고려하였다.

\section{II. 실험방법}

$240 \mathrm{~nm}$ 의 두께를 갖는 $\mathrm{Ni}$ 박막은 실리콘 웨이퍼에 $\mathrm{Au}$ 를
스퍼터링하여 working electrode(WE)를 형성한 후 전기 도금 법으로 제작하였다. 도금 용액은 증류수에 $\mathrm{NiSO}_{4} 6 \mathrm{H}_{2} \mathrm{O}(52.6$ $\mathrm{g} / 1)$ 및 $\mathrm{H}_{3} \mathrm{BO}_{3}(24 \mathrm{~g} / 1)$ 를 섞어 준비하였다. 전기 도금셀은 $\mathrm{WE}$ 와 함께 백금 판으로 된 counter electrode $(\mathrm{CE})$ 와 $\mathrm{Ag} / \mathrm{AgCl}$ reference electrode(RE)로 구성되었다. Potentiostat 장치를 이 용하여 $\mathrm{RE}$ 에 대해 $\mathrm{WE}$ 의 전위차를 $-1.0 \mathrm{~V}$ 로 일정하게 유지 하며 $\mathrm{Ni}$ 박막을 성장시켰다. 전기 도금법으로 제작된 박막의 구조는 FE-SEM(field-emission scanning electron microscope) 을 이용하여 관찰하였으며, EDX(energy dispersive X-ray)를 사용하여 박막의 성분이 $\mathrm{Ni}$ 임을 확인하였다. $\mathrm{Ni}$ 박막의 자화 곡선은 VSM(Vibrating sample magnetometer)을 이용하여 측정하였으며, 자기장의 세기에 따른 강자성 공명 신호(FMR signal)는 FMR 측정 장치인 Bruker Xepr을 사용하여 9.89 $\mathrm{GHz}$ 의 주파수에서 측정하였다. $\mathrm{Ni}$ 박막의 각도에 따른 공명 자기장 $\left(H_{r e s}\right)$ 및 선폭 $\left(\Delta H_{P P}\right)$ 특성을 분석하기 위하여 수직면 (out-of-plane)으로부터 측정한 자기장 방향의 각도 $\left(\theta_{H}\right)$ 에 따라 강자성 공명 신호를 측정하였다.

\section{III. 실험결과 및 고찰}

전기 도금법으로 제작한 $\mathrm{Ni}$ 박막의 자성 특성을 분석하기 위하여 자화 곡선을 측정하였다. 박막 재료의 두께가 면적에 비하여 매우 큰 경우 수평면 방향의 형상 이방성 요소는 무 시되고 수직면 방향의 형상이방성 요소만 고려하여 자화량을 구할 수 있다. 제조한 $\mathrm{Ni}$ 박막의 두께는 $240 \mathrm{~nm}$ 이고 폭과 너비는 약 $3 \mathrm{~mm}$ 인 시편을 사용하여 자화 곡선을 측정하였다. 이러한 크기의 $\mathrm{Ni}$ 박막에서는 수직면 방향에서 측정한 자화 곡선으로부터 얻은 형상 이방성 자기장 $\left(H_{d}=4 \pi M_{s}\right)$ 으로부터 $\mathrm{Ni}$ 박막의 포화 자화량 $\left(M_{s}\right)$ 를 구할 수 있다.

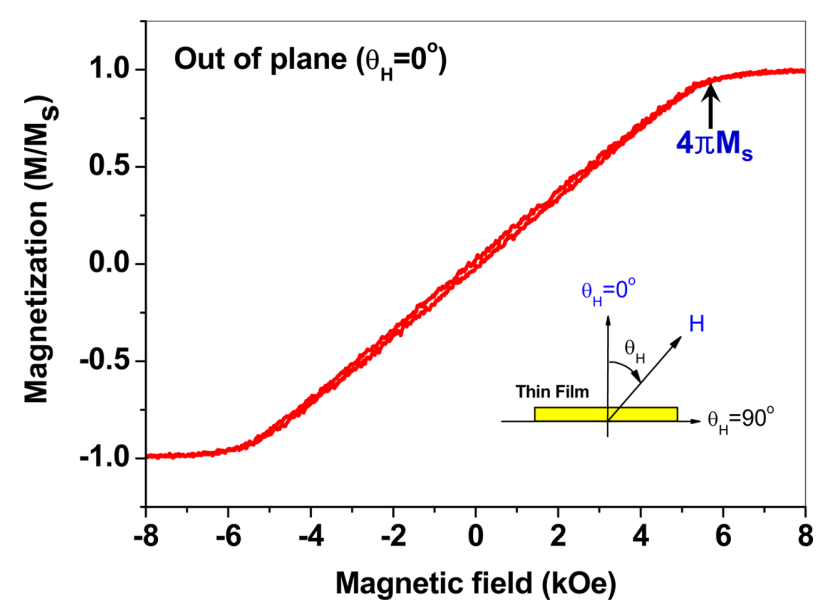

Fig. 1. (Color online) Hysteresis loop with magnetic field of $\mathrm{Ni}$ thin film at $\theta_{H}=0^{\circ}$. 


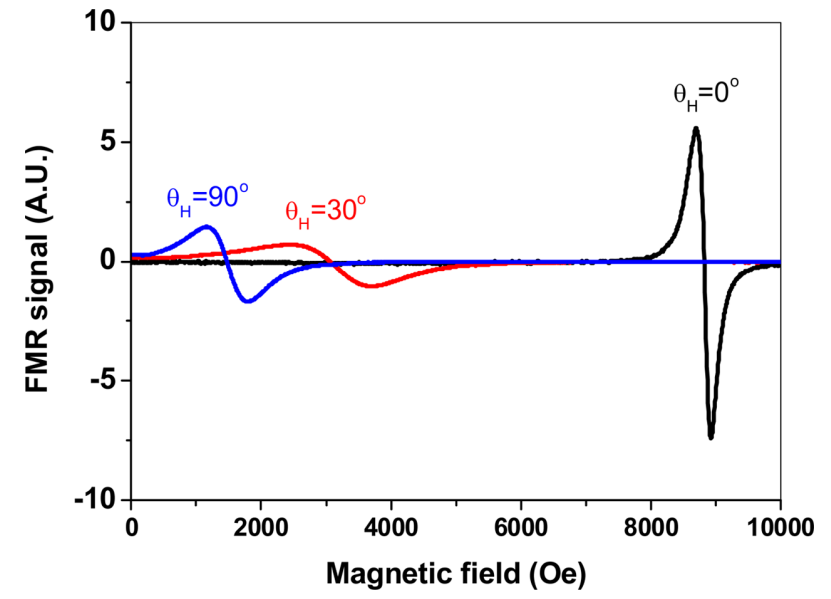

Fig. 2. (Color online) Ferromagnetic resonance (FMR) signal with magnetic field of $\mathrm{Ni}$ thin film at $\theta_{H}=90^{\circ}, 30^{\circ}$, and $0^{\circ}$.

Fig. 1에서 보인 것과 같이 $\mathrm{Ni}$ 박막의 수직면 방향에서 $\left(\theta_{H}=0^{\circ}\right)$ 측정한 자화 곡선으로부터 $\mathrm{Ni}$ 박막의 형상 이방성 자기장인 $H_{d}=5.7 \mathrm{kOe}$ 의 값을 얻었으며, $\mathrm{Ni}$ 박막의 포화 자 화량은 $M_{s}=454 \mathrm{emu} / \mathrm{cc}^{\circ}$ 임을 알 수 있었다. 따라서 전기 도 금법으로 제조한 $\mathrm{Ni}$ 박막의 자성 특성이 $\mathrm{Ni}$ 의 포화 자화량인 $484 \mathrm{emu} / \mathrm{cc}[16]$ 와 유사한 값을 가지고 있음을 확인하였다. 이 러한 $\mathrm{Ni}$ 박막을 사용하여 자기장 각도에 따른 공명 자기장 및 선폭 변화 특성을 분석하기 위하여 자기장의 세기에 따른 강자성 공명 신호를 측정하였다.

Fig. 2는 전기 도금법으로 제작한 $\mathrm{Ni}$ 박막을 사용하여 자 기장 각도가 각각 $\theta_{H}=90^{\circ}, 30^{\circ}$ 및 $0^{\circ}$ 에서 측정한 강자성 공명 신호들을 보인다. 자기장의 세기에 따른 강자성 공명 신 호는 최대값을 보인 다음 감소하여 최소값을 보인 후 증가하 여 영 $(0)$ 의 값으로 접근한다. 이때 공명 자기장은 $\left(H_{r e s}\right)$ 강자 성 공명 신호가 최대값을 지난 후 신호의 세기가 영이 되는 자기장으로 정의되며, 이는 마이크로파의 흡수 특성이 최대가 되는 강자성 공명 조건을 의미한다. 또한 선폭 $\left(\Delta H_{p p}\right)$ 은 강자 성 공명 신호가 최대가 되는 자기장과 최소가 되는 자기장의 차이로 정의되며, 자기 스핀의 자기 이완을 나타내는 감쇠 운 동과 관련된다. Fig. 2에서 보인 강자성 공명 신호로 부터 각 도가 $\theta_{H}=90^{\circ}$ 에서 $0^{\circ}$ 로 변화됨에 따라서 $H_{r e s}$ 값이 $1471 \mathrm{Oe}$ 에서 $8817 \mathrm{Oe}$ 로 변화됨을 알 수 있다. 이러한 강자성 공명 특성은 자성 재료의 자기 에너지에 의존하며, 본 연구에서 사 용한 $\mathrm{Ni}$ 박막의 자기 에너지는 다음과 같다.

$$
E=-H M_{s} \cos \left(\theta_{M}-\theta_{H}\right)+2 \pi M_{e f f}^{2} \cos ^{2} \theta_{M}
$$

여기서 $\theta_{H}$ 는 박막재료의 수직면부터 측정된 자기장 방향의 각도를 나타내며, $\theta_{M}$ 은 박막 재료의 수직면부터 움직인 자화 방향의 각도를 나타낸다. 한편 $4 \pi M_{\text {eff }}$ 는 유효 형상 이방성
자기장을 나타낸다. 자성 박막 재료의 자기장 각도 $\left(\theta_{H}\right)$ 에 따 른 $H_{r e s}$ 를 측정하여 자성 재료의 고주파수 특성을 결정 짖는 $\mathrm{g}$-factor 및 이방성 자기장 특성을 분석하는데 이용되며 이때 강자성 공명 조건은 다음과 같이 표현된다 $[4,9]$.

$$
\omega=\gamma \sqrt{H_{1} \times H_{2}}
$$

여기서 $\gamma=g \mu_{B} / \hbar$ 는 자기 스핀의 자이로 계수(gyromagnetic factor)이며, $g, \mu_{B}$, 및 $\hbar$ 는 각각 $\mathrm{g}$-factor, 보아 마그네톤 상 수 및 플랑크 상수이다. 또한 $\omega$ 는 마이크로파의 각주파수 $(\omega=2 \pi f)$ 이다. 식(2)의 $H_{1}$ 과 $H_{2}$ 는 각각 다음과 같이 표현 된다.

$$
\begin{aligned}
& H_{1}=H_{\text {res }} \cos \left(\theta_{H}-\theta_{M}\right)-4 \pi M_{e f f} \cos ^{2} \theta_{M} \\
& H_{2}=H_{\text {res }} \cos \left(\theta_{H}-\theta_{M}\right)-4 \pi M_{e f f} \cos 2 \theta_{M}
\end{aligned}
$$

식(2)에서 $\theta_{H}=0^{\circ}$ 과 $\theta_{H}=90^{\circ}$ 에 대한 평형 조건인 $\theta_{H}=\theta_{M}$ 을 대입하여 다음의 결과를 얻는다.

$$
\begin{aligned}
& \omega=\chi\left(H_{\text {res }}-4 \pi M_{\text {eff }}\right) \text { at } \theta_{H}=0^{\circ} \\
& \omega=\gamma \sqrt{H_{\text {res }}\left(H_{\text {res }}+4 \pi M_{\text {eff }}\right)} \text { at } \theta_{H}=90^{\circ}
\end{aligned}
$$

$\mathrm{Ni}$ 박막의 유효 형상 이방성 자기장 $\left(4 \pi M_{e f f}\right)$ 및 $\mathrm{g}$-factor는 $\theta_{H}=0^{\circ}$ 및 $\theta_{H}=90^{\circ}$ 에서 측정된 $H_{r e s}$ 를 식(5)과 (6)에 대입하여 구할 수 있다. 식(5)와 (6)으로부터 도출한 $\mathrm{Ni}$ 박막의 $4 \pi M_{e f f}=$ $5.6 \mathrm{kOe}\left(M_{e f f}=445.0 \mathrm{emu} / \mathrm{cc}\right)$ 를 얻었으며, 이 값은 Fig. 1의 자화 곡선으로부터 구한 $M_{s}(=454 \mathrm{emu} / \mathrm{cc})$ 값과 유사하다. 또 한 $\mathrm{Ni}$ 박막의 $\mathrm{g}$-factor는 2.18 로 전형적인 $\mathrm{Ni}$ 박막에서 얻어 진 값과 일치한다[17]. $\mathrm{Ni}$ 박막에 대한 $g=2.18$ 및 $4 \pi M_{\text {eff }}=$ $5.6 \mathrm{kOe}$ 값을 식(2)에 대입하여 $\mathrm{Ni}$ 박막의 자기장 각도에 따 른 $H_{r e s}\left(\theta_{H}\right)$ 를 계산할 수 있다. Fig. 3은 Ni 박막에 대하여

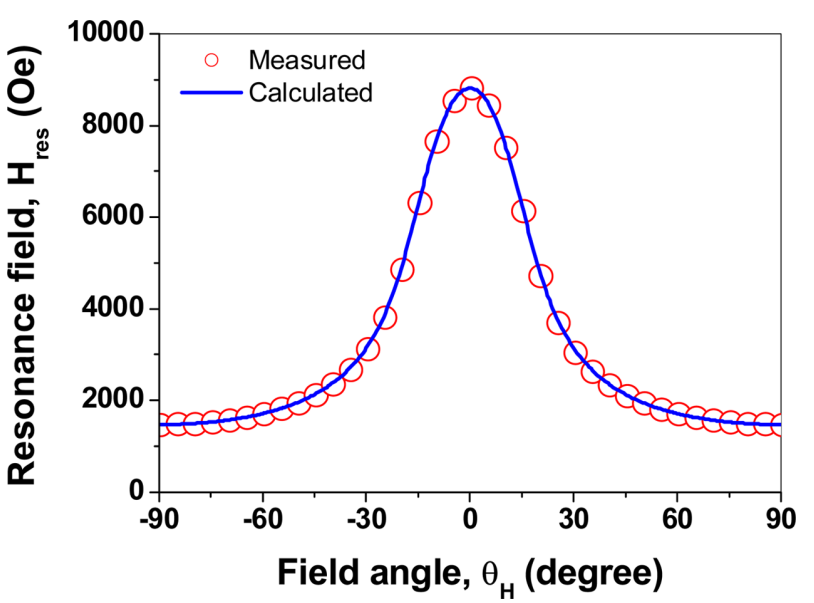

Fig. 3. (Color online) Angular dependence of $H_{r e s}$ in Ni thin film. The solid line is fitted by Eq. (2). 
자기장 각도 $\left(\theta_{H}\right)$ 에 따른 $H_{r e s}$ 의 변화 특성을 보인다. $\mathrm{Ni}$ 박막 의 자기장 각도에 따른 $H_{r e s}$ 는 전형적인 박막 재료의 공명 자 기장의 변화 특성과 동일한 양상을 보인다. 이들 측정 결과 는 식(2)를 이용하여 계산한 결과와 일치함을 알 수 있다.

강자성 공명 신호의 선폭 $\left(\Delta H_{p p}\right)$ 는 균질한 자성 재료에서 나타나는 $\Delta H_{\text {homo }}$ 와 재료의 비균질성에 의하여 유기되는 $\Delta H_{\text {inhomo }}$ 의 합으로 표현된다[1-6].

$$
\Delta H_{p p}=\Delta H_{\text {homo }}+\Delta H_{\text {inhomo }}
$$

$\Delta H_{\text {homo }}$ 는 Gilbert 감쇠(damping) 상수 $\alpha$ 를 포함하는 Landau-Lifshitz 방정식의 공명 조건을 만족하는 해로부터 다 음과 같이 표현된다[4].

$$
\Delta H_{\text {homo }}=\frac{\alpha}{\sqrt{3}}\left(H_{1}+H_{2}\right)\left|\frac{d(\omega / \gamma)}{d H_{\text {res }}}\right|^{-1}
$$

식(8)으로부터 $\Delta H_{\text {homo }}$ 는 Gilbert 감쇠(damping) 상수 $\alpha$ 에 비 례하고, 자성 재료의 고유 물성인 g-factor의 분산특성에 기인 하며 다음과 같이 표현된다[9].

$$
\Delta H_{\text {homo }}=\frac{\alpha}{\sqrt{3}} \frac{2 \omega}{\gamma F}
$$

여기서 식(9)의 $F$ 는 식(3)와 (4)을 사용하여 다음과 같이 표 현된다.

$$
F=\cos \left(\theta_{M}-\theta_{H}\right)-\frac{3 H_{1}+H_{2}}{H_{2}\left(H_{1}+H_{2}\right)} H_{r e s} \sin ^{2}\left(\theta_{M}-\theta_{H}\right)
$$

식(10)으로부터 각도에 따른 $\Delta H_{h o m o}$ 는 자화 각도와 자기장 각도의 차이인 $\theta_{M}-\theta_{H}$ 에 의존하는 것을 알 수 있다. 즉 공 명 자기장을 측정하기 위하여 인가한 자기장 각도에서 자기

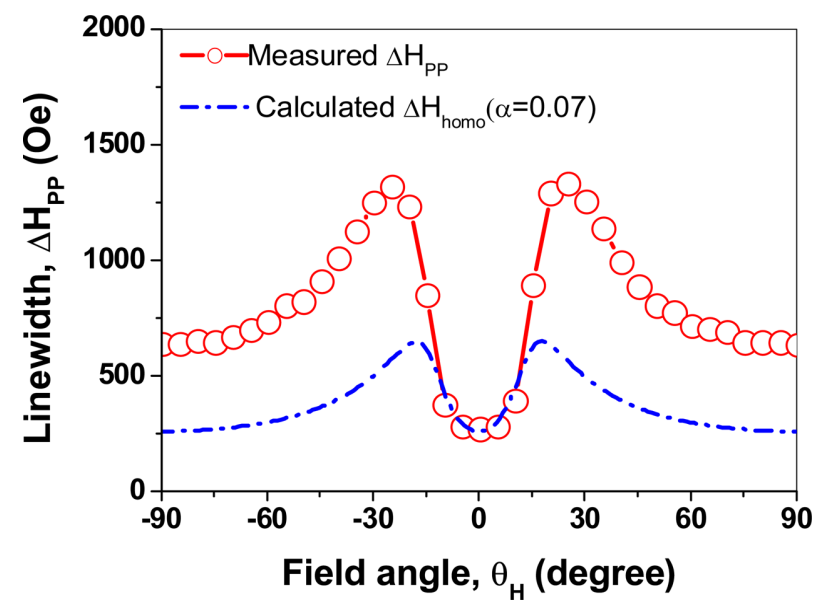

Fig. 4. (Color online) Angular dependence of $\Delta H_{p p}$ in Ni thin film. The dash line indicates the $\Delta H_{\text {homo }}$ fitted by Eq. (9) and (10) with $\alpha=0.07$.
장의 세기를 증가시켜 공명 자기장이 된 경우 자화 각도가 자기장 각도를 따라가지 못하는 지연 현상으로 $\Delta H_{\text {homo }}$ 의 각 도 의존성이 해석되므로 식(10)의 $F$ 를 지연 함수(dragging function)라고 한다[9].

Fig. 4는 $\mathrm{Ni}$ 박막에 대하여 자기장 각도 $\left(\theta_{H}\right)$ 에 따른 선폭 $\left(\Delta H_{p p}\right)$ 의 변화 특성을 보인다. 점선은 감쇠 상수 $\alpha=0.07$ 인 경우에 대하여 식(9)와 (10)을 이용하여 계산한 자성 재료의 균일한 선폭 $\left(\Delta H_{h o m o}\right)$ 특성을 보인다. $\mathrm{Ni}$ 박막의 자기장 각도 에 따른 $\Delta H_{p p}$ 변화 특성은 $\Delta H_{h o m o}$ 에 의한 특성으로 해석되 지 않음을 보인다. 전기 도금법으로 제조한 $\mathrm{Ni}$ 박막의 선폭 변화 특성은 재료의 비균일한 특성이 크게 영향을 미치고 있 음을 알 수 있다. 이러한 비균일 특성을 분석하기 위하여, 측 정된 $\Delta H_{P P}$ 에서 균일한 선폭 특성인 $\Delta H_{h o m o}$ 를 제거함으로써 비 균일한 선폭 변화를 도출하였다. Fig. 5 는 자기장 각도에 따 른 비균질한 선폭 $\left(\Delta H_{\text {inhomo }}\right)$ 변화 특성을 보인다. 비균질한 선 폭은 자기장의 각도가 $\theta_{H}=90^{\circ}$ 에의 선폭이 $\theta_{H}=0^{\circ}$ 에서의 선 폭 보다 크며, 약 $\theta_{H}=30^{\circ}$ 에서 최대가 되며, $-15^{\circ}<\theta_{H}<15^{\circ}$ 에서는 무시될 정도로 작은 값을 보인다. 이러한 비균일한 선 폭 특성은 박막 재료의 국부적인 비균일 특성 및 스핀파의 산란에 기인한다.

박막 재료의 비균일 특성은 재료 내부의 국부적인 자화량 의 비균일 특성인 $\Delta\left(4 \pi M_{e f f}\right)$, 자화 방향의 비균일 특성인 $\Delta \theta_{H}$ 및 재료 내에 존재하는 결함들에 의한 스핀파들의 산란 특성(two-magnon scattering, TMS)으로 구분된다. 자화량의 비균일 특성은 박막의 표면 효과로 약 $1 \mathrm{~nm}$ 정도의 두께가 영향을 미치는 것으로 보고 있다[9]. 따라서 자화량의 비균일 특성은 두께가 얇은 약 $10 \mathrm{~nm}$ 이하의 박막에서 두드러지게 나타나며, $\theta_{H}=90^{\circ}$ 에의 선폭이 $\theta_{H}=0^{\circ}$ 에서의 선폭 보다 작게 나타난다. 이러한 특성은 Fig. 5 에서 보인 결과와 반대의 특

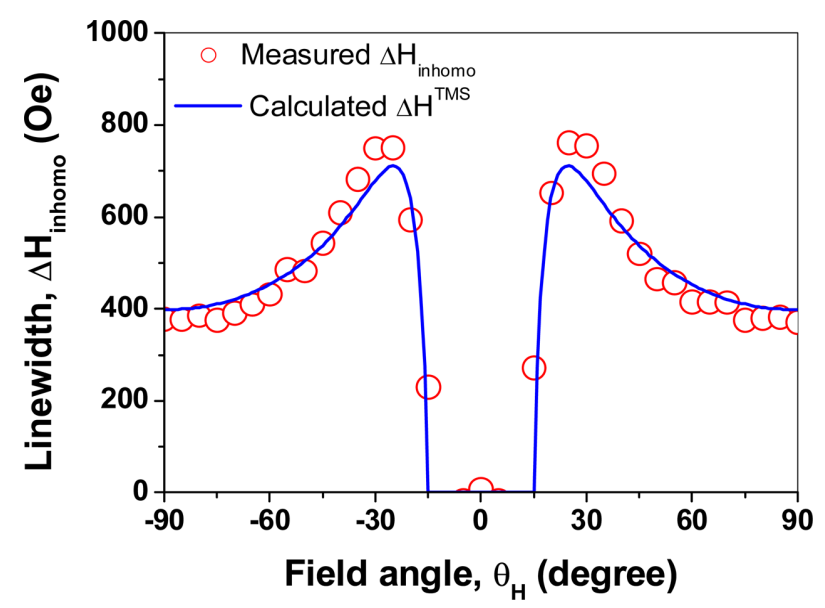

Fig. 5. (Color online) Angular dependence of $\Delta H_{\text {inhomo }}$ in Ni thin film. The solid line is fitted by two magnon scattering $\left(\Delta H^{T M S}\right)$ by using Eq. (11) and (12). 
성이다. 또한 자화 방향의 비균일에 의한 선폭 변화는 $\theta_{H}=$ $90^{\circ}$ 에의 선폭이 $\theta_{H}=0^{\circ}$ 에서의 선폭과 같은 값을 가지며, $\theta_{H}=$ $0^{\circ}$ 에서의 선폭 변화는 Fig. 5 에서 보인 것과는 상이한 V자형 을 형성한다. 한편, 자성 박막에서 스핀파의 산란은 스핀파가 진행할 수 있는 임계 두께 $\left(t_{c}\right)$ 이상에서 나타나며 $\left(t_{c}=2 \pi / k, k\right.$ 는 스핀파의 파수), 자화 각도가 $\theta_{M}<45^{\circ}$ 에서 나타난다. $\mathrm{Ni}$ 의 경우 마이크로파 주파수가 $10 \mathrm{GHz}$ 에서 $t_{c}$ 는 약 $50 \mathrm{~nm}$ 이 므로 $240 \mathrm{~nm}$ 의 두께를 갖는 박막에서는 스핀파의 산란 특성 이 나타날 수 있다. 따라서 $240 \mathrm{~nm}$ 의 두께를 갖는 $\mathrm{Ni}$ 박막 의 비균일한 선폭 변화를 분석하기 위하여 스핀파의 산란에 의한 TMS 해석법을 $\left(\Delta H^{T M S}\right)$ 사용하였다[9].

$$
\Delta H^{T M S}=\frac{2}{\sqrt{3}} \Gamma\left(H_{r e s}, \theta_{H}\right) \sin ^{-1} \sqrt{\frac{-H_{1} \cos \left(2 \theta_{M}\right)}{\left(H_{1}+4 \pi M_{e f f}\right) \sin ^{2} \theta_{M}}}
$$

여기서 $\Gamma\left(H_{r e s}, \theta_{H}\right)$ 는 다음과 같이 표현된다[9].

$$
\Gamma\left(H_{\text {res }}, \theta_{H}\right)=\Gamma_{0} \frac{H_{1} \cos \left(2 \theta_{M}\right)-H_{2} \sin ^{2} \theta_{M}}{\left(H_{1}+H_{2}\right)^{2} F}
$$

Fig. 5에서 보인 실선은 $\Gamma_{0}=1062 \mathrm{Oe}$ 를 식(11)과 (12)에 대 입하여 계산한 결과를 보이며, 비균일한 선폭은 $\mathrm{TMS}$ 에 의한 영향이 가장 중요한 요인임을 알 수 있다. 본 연구를 통하여 $240 \mathrm{~nm}$ 의 두께를 갖는 $\mathrm{Ni}$ 박막의 자기장 각도에 따른 비균 일한 선폭의 변화 특성은 스핀파의 산란에 의한 $\Delta H^{T M S}$ 에 의 한 영향이 가장 크게 작용하고 있음을 알 수 있었다.

\section{IV. 결 론}

전기 도금법으로 $\mathrm{Ni}$ 박막 $(240 \mathrm{~nm})$ 을 제조하여 박막의 수직 면으로부터 자기장 방향의 각도에 따른 강자성 공명 신호를 측정하여 공명 자기장 $\left(H_{r e s}\right)$ 및 선폭 $\left(\Delta H_{P P}\right)$ 을 도출하였다. 자 기장 각도에 따른 $H_{r e s}$ 는 이론적인 분석 결과와 일치하였으며 이들 결과로부터 제조된 $\mathrm{Ni}$ 박막의 g-factor는 2.18 임을 확인 하였다. 자기장 각도에 따른 $\triangle H_{P P}$ 는 박막의 수직방향 보다 수평방향에서 매우 큰 값을 나타냈다. 이러한 변화는 자화 상 태가 균일한 자성 재료에 대하여 고려하는 Gilbert 감쇠에 의 존하는 균일한 선폭 $\left(\Delta H_{\text {homo }}\right)$ 특성으로는 해석되지 않았으며, 비균일한 선폭 $\left(\Delta H_{\text {inhomo }}\right)$ 특성의 해석이 필요하였다.

비균일한 선폭은 재료 내부 자화 상태들의 국부적인 비균 일성에 기인하는 자구들의 각도 변화 및 자화량 변화 특성과 스핀파의 산란에 기인하는 특성으로 구분된다. 자성 박막 재 료에서 자구들의 각도 변화 및 자화량 변화에 의한 선폭 특 성은 표면의 거칠기에 의한 자화 각도 변화 및 자화량 변화 에 기인한다. 이러한 표면 효과는 약 $1 \mathrm{~nm}$ 두께의 범위에 두 드러지게 나타나므로 박막의 두께가 약 $10 \mathrm{~nm}$ 이하의 자성
박막에서 현저하게 나타나는 선폭 변화 특성이다. 본 연구에 서 사용한 $\mathrm{Ni}$ 박막은 두께가 $240 \mathrm{~nm}$ 이므로 자구들의 각도 변화 및 자화량 변화는 비균질한 선폭에 미치는 영향이 미미 하였다.

한편, 자성 재료의 두께가 스핀파가 진행할 수 있는 임계 두께 이상에서는 재료 내부의 결함들에 의하여 스핀파 산란 에 의한 선폭 특성이 나타난다. $\mathrm{Ni}$ 박막의 경우 임계 두께는 $10 \mathrm{GHz}$ 에서 약 $50 \mathrm{~nm}$ 이며, $240 \mathrm{~nm}$ 두께는 임계 두께 이상 이므로 스핀파의 산란 특성을 고려할 수 있었다. 따라서, 본 연구에서는 재료의 내부 결함들에서 산란하는 스핀파들의 영 향을 고려한 two magnon scattering(TMS) 해석법을 사용하 여 비균일한 선폭 특성을 분석하였으며 실험 결과와 계산결 과가 거의 일치함을 확인하였다. 따라서 전기 도금법으로 제 작한 $\mathrm{Ni}$ 박막 $(240 \mathrm{~nm})$ 의 자기이완 특성을 분석하기 위해서는 Gilbert 감쇠 특성뿐만 아니라 내부 결함에 의한 스핀파의 산 란특성을 동시에 고려하여야 함을 알 수 있었다.

\section{감사의 글}

이 논문은 2010년도 정부(교육과학기술부)의 재원으로 한 국연구재단의 기초연구사업 지원을 받아 수행된 것임 (NRF2010-0008282).

\section{References}

[1] W. Platow, A. N. Anisimov, G. L. Dunifer, M. Farle, and K. Baberschke, Phys. Rev. B 58, 5611 (1998).

[2] S. J. Yuan, L. Sun, H. Sang, J. Du, and S. M. Zhou, Phys. Rev. B 68, 134443 (2003).

[3] S. Misukami, Y. Ando, and T. Miyazaki, Jpn. J. Appl. Phys. 40, 580 (2001).

[4] M. Oogane, T. Wakitani, S. Yakata, R. Yilgin, Y. Ando, A. Sakuma, and T. Miyazaki, Jpn. J. Appl. Phys. 45, 3889 (2006).

[5] S. Yuan, K. Yu, L. M. Yu, S. X. Cao, C. Jing, and J. C. Zhang, J. Appl. Phys. 101, 113915 (2007).

[6] S. Yuan, B. Kang, L. Yu, S. Cao, and X. Zhao, J. Appl. Phys. 105, 063902 (2009).

[7] S. Yuan, L. Wang, R. Shan, and S. M. Zhou, Appl. Phys. A 79, 701 (2004).

[8] J. P. Nibarger, R. Lopusnik, Z. Celinsk, and T. J. Silva, Appl. Phys. Lett. 83, 93 (2003).

[9] J. Linder, I. Barsukov, C. Raeder, C. Hassel, O. Posth, R. Meckenstock, P. Landeros, and D. L. Mills, Phys. Rev. B 80, 224421 (2009).

[10] P. Landeros, R. E. Arias, and D. L. Mills, Phys. Rev. B 77, 214405 (2008).

[11] P. K. Krivosik, N. Mo, S. Kalarickal, and C. E. Patton, J. Appl. Phys. 101, 083901 (2007). 
[12] K. Lenz, H. Wende, W. Kuch, K. Baberschke, K. Nagy, and A.Janossy, Phys. Rev. B 73, 144424 (2006).

[13] M. J. Hurben and C. E. Patton, J. Appl. Phys. 83, 4344 (1998).

[14] C. E. Patton, C. H. Wilts, and F. Humphrey, J. Appl. Phys. 38, 1358 (1967).

[15] C. Nistor, K. Sun, Z. Wang, M. Wu, C. Mathieu, and M. Had- ley, Appl. Phys. Lett. 95, 012504 (2009).

[16] B. D. Cullity and C. D. Graham, Introduction to Magnetic Materials, Wiley (2009) p. 116.

[17] U. Ebels, J. L. Duvail, P. E. Wigen, L. Piraux, L. D. Buda, and K. Ounadjela, Phys. Rev. B 64, 144421 (2001). 